\title{
Hydrochar: A Review on Its Production Technologies and Applications
}

\author{
Shima Masoumi, Venu Babu Borugadda (D, Sonil Nanda and Ajay K. Dalai * \\ Department of Chemical and Biological Engineering, University of Saskatchewan, \\ Saskatoon, SK S7N 5A9, Canada; shm677@mail.usask.ca (S.M.); vbb123@mail.usask.ca (V.B.B.); \\ sonil.nanda@usask.ca (S.N.) \\ * Correspondence: ajay.dalai@usask.ca; Tel.: +306-966-4771
}

check for updates

Citation: Masoumi, S.; Borugadda, V.B.; Nanda, S.; Dalai, A.K.

Hydrochar: A Review on Its Production Technologies and Applications. Catalysts 2021, 11, 939. https://doi.org/10.3390/catal11080939

Academic Editors: Omid Norouz Pietro Bartocci and Somayeh Taghavi

Received: 1 July 2021

Accepted: 29 July 2021

Published: 2 August 2021

Publisher's Note: MDPI stays neutral with regard to jurisdictional claims in published maps and institutional affiliations.

Copyright: (c) 2021 by the authors. Licensee MDPI, Basel, Switzerland. This article is an open access article distributed under the terms and conditions of the Creative Commons Attribution (CC BY) license (https:// creativecommons.org/licenses/by/ $4.0 /)$.

\begin{abstract}
Recently, due to the escalating usage of non-renewable fossil fuels such as coal, natural gas and petroleum coke in electricity and power generation, and associated issues with pollution and global warming, more attention is being paid to finding alternative renewable fuel sources. Thermochemical and hydrothermal conversion processes have been used to produce biochar and hydrochar, respectively, from waste renewable biomass. Char produced from the thermochemical and hydrothermal decomposition of biomass is considered an environmentally friendly replacement for solid hydrocarbon materials such as coal and petroleum coke. Unlike thermochemically derived biochar, hydrochar has received little attention due to the lack of literature on its production technologies, physicochemical characterization, and applications. This review paper aims to fulfill these objectives and fill the knowledge gaps in the literature relating to hydrochar. Therefore, this review discusses the most recent studies on hydrochar characteristics, reaction mechanisms for char production technology such as hydrothermal carbonization, as well as hydrochar activation and functionalization. In addition, the applications of hydrochar, mainly in the fields of agriculture, pollutant adsorption, catalyst support, bioenergy, carbon sequestration, and electrochemistry are reviewed. With advancements in hydrothermal technologies and other environmentally friendly conversion technologies, hydrochar appears to be an appealing bioresource for a wide variety of energy, environmental, industrial, and commercial applications.
\end{abstract}

Keywords: hydrochar; biochar; hydrothermal carbonization; bioenergy; carbon

\section{Introduction}

In recent decades, many researchers have focused on finding sustainable sources for fuel production due to the incremental worldwide energy demand, environmental concerns related to greenhouse gas emissions, and the finite supply of energy from non-renewable fossil fuels [1-3]. Biomass, which is considered a sustainable energy source, is one of the most abundant sources of renewable energy. Biomass can be classified as wet with the moisture content of $>30 \mathrm{wt} . \%$ and dry with the moisture content of $<30 \mathrm{wt} . \%$. The selection of conversion technologies would depend on this classification. The examples of dry biomasses are woody, herbaceous, and agricultural biomass, whereas wet biomasses include algae, sewage sludge, cattle manure, and industrial effluents $[4,5]$.

Biomass can be converted to biofuels (liquid and/or solid), through thermochemical and biological processes. Biomass undergoes different and complicated chemical reactions such as dehydration, decarboxylation, decarbonylation and depolymerization to produce biofuels. Reaction temperature has significant impacts on which reactions dominate and, generally, some of these reactions are carried out simultaneously during the process [6]. Pyrolysis and hydrothermal carbonization (HTC) are two routes of thermochemical conversion technology for the production of bio/hydrochar as the main products (Figure 1). These thermochemical processes are employed to convert the biomass containing the organic compounds to carbon-rich materials. Compared to slow pyrolysis, the hydrothermal 
carbonization process is considered a promising technology due to the elimination of the drying step. Moreover, HTC is mostly considered economically viable for wet biomass [7,8].

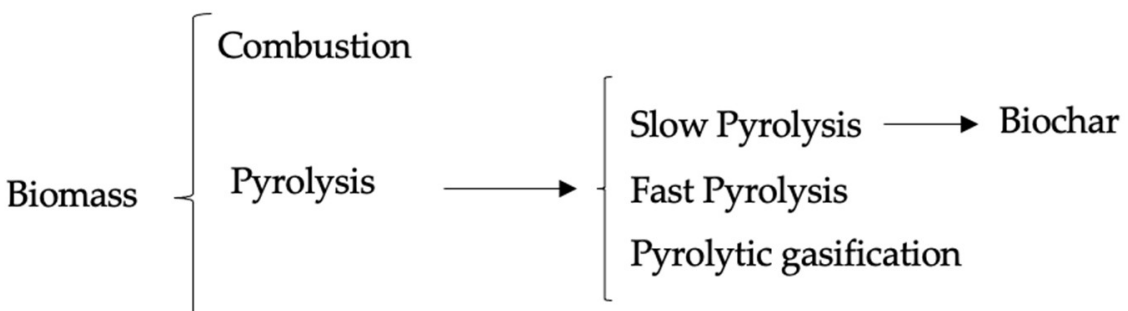

Hydrothermal process

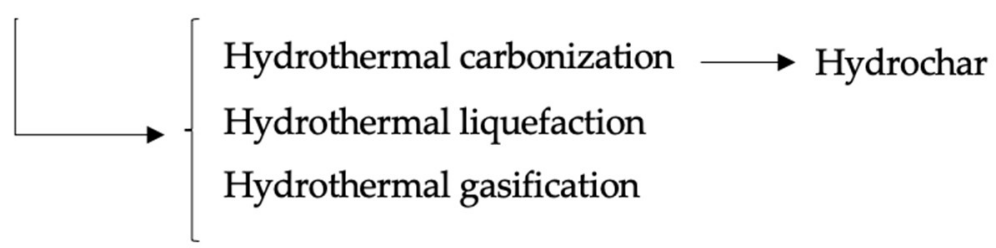

Figure 1. Conversion pathways from biomass to bio/hydrochar.

Hydrothermal carbonization is usually carried out at temperatures ranging from $180{ }^{\circ} \mathrm{C}$ to $240{ }^{\circ} \mathrm{C}$ for $5-240$ min under subcritical water pressures $[9,10]$. Pyrolysis is performed at a reaction temperature of $300-650{ }^{\circ} \mathrm{C}$ in the absence of oxygen. The products are divided into biochar, which is not fully carbonized, liquid phase, and gas phase. Moreover, depending on the reaction time and heating rate, the pyrolysis process is divided into different categories such as fast, intermediate, and slow. Slow-pyrolysis is performed with a low heating rate and long residence time, resulting in a higher solid product yield [11,12].

The carbon materials include carbon fibers, structural graphite, carbon nanotubes, graphene, and carbon foams, which can be employed in different sectors such as aerospace, electronics, automotive, and construction. Recently, the demand for carbon materials has incrementally increased. Moreover, the high cost of production of carbon materials such as activated carbon using non-renewable petroleum precursors has been considered as one of the environmental concerns. Therefore, the global demand to produce carbon materials using renewable sources has increased with an annual rate of $10 \%[13,14]$. Bio/hydrochar has received much attention as its feedstocks are abundantly available, renewable and inexpensive [7,15].

As was mentioned previously, due to the incremental human population and industrialization, there is a concern related to the greenhouse gas emission by burning fossil fuels as a source of energy to produce value-added products as well as to improve food availability. Thus, the other advantages of utilizing bio/hydrochar for the production of the carbon materials or their application as a soil amendment can be related to global concerns, such as $\mathrm{CO}_{2}$ emission reduction, pollution control, sustainable land use, and energy storage [16].

A lot of researches have focused on biochar utilization as adsorbents or catalysts/catalyst support, carbon sequestration agent, wastewater treatment, soil amendment, and electrode materials [17-19]. Recently, there has been an incremental interest in hydrochar production and utilization. However, a comprehensive study of the physicochemical properties of hydrochar, and the recent advances in the production of hydrochar from biomass, have not yet been reviewed. This review is mainly focused on the following aspects:

(i) Physical and chemical properties of hydrochar compared with that of biochar

(ii) Hydrochar production techniques (hydrothermal carbonization, liquefaction, and gasification)

(iii) Production of highly porous activated carbons through modification of hydrochar or physical and chemical activation methods 
(iv) Applications of activated hydrochar in pollutant adsorption, catalysts support, carbon sequestration, wastewater treatment, and pharmaceutical and cosmetic applications.

\section{Hydrochar versus Biochar}

Hydrochar and biochar show different physicochemical properties that significantly affect their potential applications. They reveal different chemical compositions and porous characteristics, as the biomass feedstock undergoes complex chemical reactions such as degradation, dehydration, and repolymerization in different reaction conditions (e.g., temperature, heating rate, time, and pressure). Hence, they can be significantly distinguished. Reaction conditions can affect significantly the yield and characteristics of hydrochar and biochar [20,21].

The reaction temperature has a significant impact on physicochemical properties and the yield of biochar and hydrochar as the reaction temperature influences which reaction mechanism dominates. Compared to the pyrolysis used for the production of biochar, hydrothermal carbonization is performed at a lower temperature due to the availability of hot water during the reaction. Regarding the yield of a solid product, there is a relationship between temperature, carbon conversion, and yield. In this process, a lower temperature and residence time leads to a high yield of solid product and low carbon conversion and higher heating value (HHV) [22,23]. As the HTC process occurs at a lower temperature, the carbon conversion is lower than in pyrolysis, resulting in higher atomic $\mathrm{H} / \mathrm{C}$ and $\mathrm{O} / \mathrm{C}$ ratios. Thus, hydrochar has higher atomic ratios of hydrogen to carbon and oxygen to carbon, compared to those in biochar [24,25].

Biomass contains hemicellulose, cellulose, and lignin. Cellulose is composed of monomers of glucose allied with glycoside bond, while hemicellulose consists of sugar acids, pentoses and hexoses. Lignin, being a polymer, is built up of phenylpropane units that provide rigidity to the plant cells and bind cellulose and hemicellulose together [26]. As the temperature increases, the hemicellulose, which contains lower energy density, starts decomposing, and the lignin with higher energy density remains in the solid product, resulting in a higher HHV. During hydrothermal carbonization, which is carried out at a lower temperature in water media, hemicellulose could be decomposed faster [27]. Thus, hydrochar has a higher HHV compared to biochar. In addition, as hydrochar is produced through the HTC process in the water media, inorganic compositions of biomass are demineralized, resulting in the reduction of ash content. Thus, compared to biochar, which is produced through pyrolysis, hydrochar contains less ash content [28].

The reaction conditions significantly affect the surface and structure characteristics of hydrochar and biochar. Regarding the aromaticity of hydrochar and biochar, biochar from pyrolysis produced at higher temperatures $\left(500-600^{\circ} \mathrm{C}\right)$ contains aromatic groups, and hydrochar from HTC produced at a lower temperature $\left(200-250^{\circ} \mathrm{C}\right)$ contains more alkyl moieties. Moreover, as the pyrolysis occurs at the higher temperature, biochar revealed a lower $\mathrm{H} / \mathrm{C}$ ratio due to high carbon conversion and possesses graphite-like layers, including particles with different size ranges, while the surface of hydrochar samples is composed of spherical particles including more homogeneous particle sizes [29,30].

Hydrochar compared to biochar is slightly acidic, as hydrochar contains more oxygenated functional groups. However, due to the loss of carboxyl and hydroxyl groups during pyrolysis, biochar is alkaline. Moreover, alkaline $\mathrm{pH}$ is attributed to inorganic and metal compounds such as $\mathrm{Ca}$ and $\mathrm{Mg}$. During HTC, some of the inorganics would be washed away in water media, resulting in acidic $\mathrm{pH}$ levels of hydrochar [31,32].

The properties of biochar depend on the biomass properties, reaction temperature, heating rate and reaction time [33]. Hydrochar generally shows a very low specific surface area and porosity. In the case of pyrolysis, a high temperature and heating rate may destroy the porous structure and clog the pores, resulting in a lower specific surface area. Thus, the specific surface area of biochars obtained from pyrolysis could increase by increasing the temperature and, after reaching the maximum, could decrease due to the pores clogging [34,35]. 
Chun et al. [36] studied the pyrolysis of wheat residue to produce biochar at a temperature range of $300-700{ }^{\circ} \mathrm{C}$, resulting in the production of biochar with a specific surface area in the range of $309-438 \mathrm{~m}^{2} / \mathrm{g}$. The specific surface area of the biochar increased by increasing the temperature up to $600^{\circ} \mathrm{C}$. However, the surface area of biochar produced at $700{ }^{\circ} \mathrm{C}$, which was $363 \mathrm{~m}^{2} / \mathrm{g}$, was lower than that produced at $600{ }^{\circ} \mathrm{C}$ with a specific surface area of $438 \mathrm{~m}^{2} / \mathrm{g}$. Angin [34] studied the physicochemical properties of biochars obtained from safflower seed cake, which is used as animal feed, based on different ranges of temperatures $\left(400-600^{\circ} \mathrm{C}\right)$ and heating rates $\left(10-50^{\circ} \mathrm{C} / \mathrm{min}\right)$. The study showed that, by increasing temperature and heating rate, the yield of biochars decreases. Moreover, the $\mathrm{pH}$ of biochars, as well as the aromatic contents, increased when the temperature was increased. In addition, by increasing temperature, the carbon content of the biochars and higher heating value (HHV) increased. In terms of Brunauer-Emmett-Teller (BET) analysis, the specific surface area did not change significantly, which was in the range of 2.7-4.2 $\mathrm{m}^{2} / \mathrm{g}$. Table 1 summarizes the different physicochemical properties of hydrochar and biochar obtained from HTC and pyrolysis, respectively.

Table 1. Comparison of physicochemical properties of hydrochar and biochar [31,32,34].

\begin{tabular}{ccc}
\hline Properties & Hydrochar & Biochar \\
\hline Specific surface area and porosity & Non-porous, low specific surface area & $\begin{array}{c}\text { Porous and depends on the reaction } \\
\text { temperature could exhibit higher specific } \\
\text { surface area }\left(>400 \mathrm{~m}^{2} / \mathrm{g}\right)\end{array}$ \\
\hline Morphology & Spherical shape & Graphite-like layers \\
\hline Total carbon content & $58-64 \mathrm{wt} . \%$ & $60-80 \mathrm{wt} . \%$ \\
\hline H/C molar ratio & $>2.3$ & $>1.5$ \\
\hline $\mathrm{O} / \mathrm{C}$ molar ratio & $>1.7$ & $>0.7$ \\
\hline $\mathrm{pH}$ & Mostly acidic & Mostly alkaline \\
\hline Aromaticity & Contains alkyl moieties & Contains aromatic groups \\
\hline
\end{tabular}

\section{Hydrochar Production Technologies}

Hydrothermal technologies are considered to be promising technologies to produce valuable products from wet biomasses through the elimination of the high energyconsuming drying step, which can be categorized into three technologies (carbonization, liquefaction and gasification) based on their operating conditions [37,38]. Moreover, hydrothermal technologies, which can be considered theoretically carbon-neutral, play a critical role due to their increasing demand as well as growing environmental concerns.

As shown in Figure 1, in addition to hydrothermal carbonization, which is used to produce hydrochar as the main solid product, there are two more processes such as hydrothermal liquefaction (HTL) and hydrothermal gasification (HTG) used to produce hydrochar as a by-product or co-product alongside bio-crude oil and syngas. The objective of the production of hydrochar as a suitable sustainable adsorbent or catalysts/catalyst support through HTL and HTG is to reduce waste materials and provide energy [39,40]. Figure 2 shows the mechanism of formation of hydrochar from biomass, which consists of cellulose, hemicellulose, and lignin. These components undergo a series of hydrolysis, isomerization, and dehydration to produce intermediates such as furfural and finally polymerization to produce hydrochar [41]. 


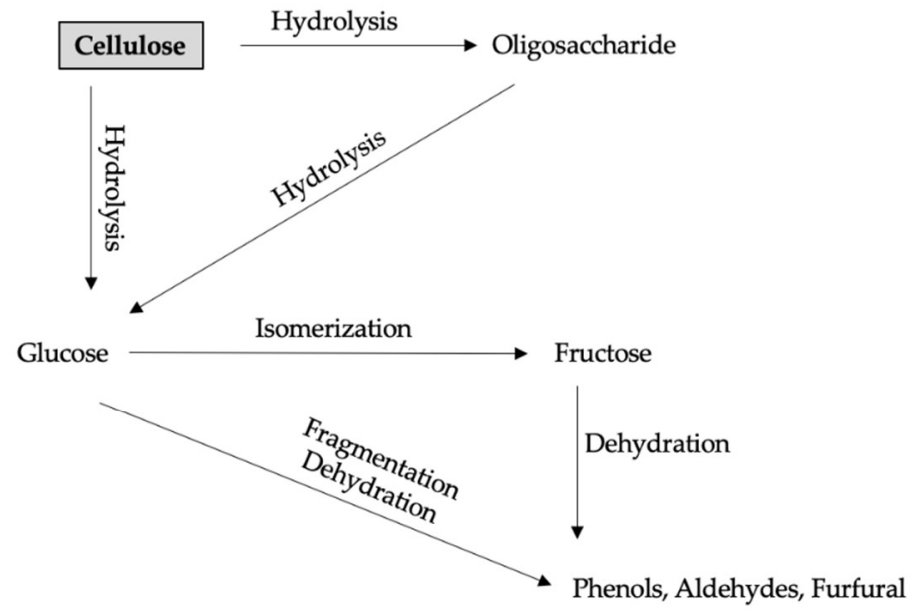

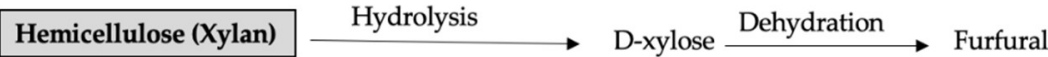

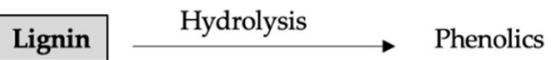

Figure 2. Proposed reaction network for hydrochar production.

The hydrothermal liquefaction (HTL) process is performed at moderate temperature $\left(200-400^{\circ} \mathrm{C}\right)$ and high pressure (10-25 MPa) in water media to produce liquid fuel (biocrude oil) as the main product. In addition, the solid (hydrochar), aqueous, and gas phases are produced as co-products of the process. The suitable utilization of hydrochar, which could be used as a source of heat for the process, could improve the economic feasibility, thus hydrochar characterization is important [42-44].

Some researchers have focused on the HTL of biomasses in water-alcohol co-solvent. As alcohols have a lower critical temperature and pressure compared to water, their addition would reduce the pressure and temperature of the HTL process. It has been shown that the addition of alcohols into the system could improve the yield and physicochemical properties of hydrochar [45-48]. For example, Masoumi et al. [45] studied the HTL of microalgae in a methanol-water system to produce and characterize bio-crude oil and hydrochar in sub-super critical conditions. All produced hydrochar revealed low porous characteristics showing a low specific surface area of $4 \mathrm{~m}^{2} / g$ and a pore volume of less than $0.02 \mathrm{~cm}^{3} / \mathrm{g}$. FT-IR results showed that supercritical conditions using water or a methanol-water co-solvent system resulted in a reduction of hydroxyl functionalities. The addition of methanol along with water for the HTL process resulted in the presence of more carboxylic acid/ester groups. Regarding the thermal stability of the produced hydrochar, higher reaction temperatures resulted in hydrochar production with higher stability, since the amount of fixed carbon in hydrochar increased, and its volatile compounds decreased because of the increasing temperature.

Hydrothermal gasification is a promising thermochemical technology used to convert carbon-rich biomass into hydrogen, methane, $\mathrm{CO}_{2}, \mathrm{CO}$, and small amounts of higher hydrocarbons as the main products using pressurized hot water. The produced gas can be employed as a heat resource, or it can be further processed to produce more hydrogen-rich gas products. Supercritical water conditions increased the rate of decomposition of biomass, resulting in a lower yield of hydrochar [49-51].

In Tables 2 and 3, different biomasses and reaction conditions are summarized for hydrochar production through hydrothermal carbonization and liquefaction. The hydrochar yield through hydrothermal gasification is not significant enough to consider it a source of solid fuel. The reaction condition required for this process is above the supercritical point of water. This severe condition is suitable to produce biogas composition. Hydrothermal carbonization has been considered as the main process used for hydrochar production, in 
which the yield of the produced hydrochar is higher than two other hydrothermal technologies for hydrochar production. In addition, according to the data mentioned in Tables 2 and 3, the hydrochar properties such as yield, carbon content, and HHV are highly dependent on feedstock and the reaction conditions of the hydrothermal process. Increasing the reaction temperature and time results in a decrease in the yield of produced hydrochar. On the other hand, increasing the temperature and time results in higher removal of volatile compounds, therefore the carbon content of hydrochar increases and the oxygen content decreases. Moreover, the temperature had more significant effects on the hydrochar yield and its characteristics as compared to the time.

Table 2. Hydrothermal carbonization process to produce hydrochar from different feedstocks.

\begin{tabular}{|c|c|c|c|c|c|c|c|}
\hline Feedstock & $\begin{array}{c}\text { Temperature } \\
\left({ }^{\circ} \mathrm{C}\right)\end{array}$ & Time (h) & $\begin{array}{l}\text { Hydrochar } \\
\text { Yield (wt.\%) }\end{array}$ & $\begin{array}{l}\text { Carbon } \\
\text { Content } \\
\text { (wt.\%) }\end{array}$ & $\begin{array}{c}\text { Atomic H/C } \\
\text { Ratio }\end{array}$ & $\begin{array}{l}\text { Higher } \\
\text { Heating } \\
\text { Value } \\
(\mathrm{MJ} / \mathrm{kg})\end{array}$ & References \\
\hline \multirow{3}{*}{$\begin{array}{c}\text { Chinese fan } \\
\text { palm }\end{array}$} & 180 & 1 & 61 & 55.9 & 1.64 & 24.2 & \multirow{3}{*}{ [52] } \\
\hline & 210 & 1 & 57 & 58.1 & 1.6 & 25.3 & \\
\hline & 240 & 1 & 50 & 64.1 & 1.5 & 28.1 & \\
\hline \multirow{3}{*}{$\begin{array}{l}\text { Chinese fan } \\
\text { palm }\end{array}$} & 210 & 0.5 & 60 & 57.3 & 1.62 & 24.9 & \multirow{3}{*}{ [52] } \\
\hline & 210 & 1 & 57 & 58.1 & 1.60 & 25.3 & \\
\hline & 210 & 1.6 & 57 & 59.6 & 1.62 & 26.4 & \\
\hline \multirow{6}{*}{$\begin{array}{l}\text { Apple chip } \\
\text { pomace } \\
\text { Grape } \\
\text { pomace } \\
\text { Rotten apple } \\
\text { Apple juice } \\
\text { pomace }\end{array}$} & & \multirow{6}{*}{-} & \multirow{6}{*}{-} & & & \multirow{6}{*}{-} & \multirow{6}{*}{ [53] } \\
\hline & 190 & & & 55.9 & 0.13 & & \\
\hline & 190 & & & 55.7 & 0.1 & & \\
\hline & 190 & & & 62.5 & 0.09 & & \\
\hline & 190 & & & 53.9 & 0.11 & & \\
\hline & & & & & & & \\
\hline \multirow{2}{*}{$\begin{array}{l}\text { Bamboo } \\
\text { shoot shell }\end{array}$} & 210 & 0.5 & 56.4 & 51.3 & \multirow{2}{*}{-} & \multirow{2}{*}{-} & \multirow{2}{*}{ [54] } \\
\hline & 270 & 0.5 & 31.9 & $>52$ & & & \\
\hline \multirow{2}{*}{$\begin{array}{l}\text { Corn cob } \\
\text { residue }\end{array}$} & 250 & \multirow{2}{*}{0.55} & 46.6 & 61.7 & 0.08 & 24.3 & \multirow{2}{*}{ [55] } \\
\hline & 250 & & 45.7 & 63.6 & 0.07 & 24.9 & \\
\hline \multirow{5}{*}{ Cotton stalk } & 180 & & 60 & 51.2 & 1.2 & & \multirow{5}{*}{ [56] } \\
\hline & 200 & & 55 & 53.2 & 1.3 & & \\
\hline & 220 & 4 & 40 & 59 & 1.1 & - & \\
\hline & 240 & & 35 & 69 & 0.91 & & \\
\hline & 260 & & 32 & 70.4 & 0.94 & & \\
\hline \multirow{5}{*}{ Cotton stalk } & \multirow{5}{*}{240} & 1 & & 61.9 & 0.92 & & \multirow{5}{*}[56]{} \\
\hline & & 2 & & 64.8 & 1.03 & & \\
\hline & & 4 & 240 & 69 & 0.91 & - & \\
\hline & & 6 & & 69.6 & 0.94 & & \\
\hline & & 8 & & 70.6 & 0.92 & & \\
\hline Green waste & 190 & 1 & 80 & 48.8 & 1.2 & 19.2 & [57] \\
\hline \multirow{3}{*}{$\begin{array}{c}\text { Moso } \\
\text { bamboo }\end{array}$} & 220 & & 51.8 & & & 19.8 & \multirow{3}{*}{ [58] } \\
\hline & 260 & 1 & 40.5 & - & - & 28.3 & \\
\hline & 300 & & 35.6 & & & 29.3 & \\
\hline \multirow{2}{*}{ Rice husk } & 200 & 6 & 66 & 40.8 & 1.27 & 15.7 & \multirow{2}{*}{ [59] } \\
\hline & 300 & 6 & 43 & 45.6 & 0.84 & 17.8 & \\
\hline
\end{tabular}


Table 3. Hydrothermal liquefaction process to produce hydrochar from different feedstocks.

\begin{tabular}{|c|c|c|c|c|c|c|c|}
\hline Feedstock & $\begin{array}{c}\text { Hydrochar } \\
\text { Yield }\end{array}$ & $\begin{array}{c}\text { Temperature } \\
\left({ }^{\circ} \mathrm{C}\right)\end{array}$ & $\begin{array}{l}\text { Time } \\
\text { (h) }\end{array}$ & $\begin{array}{l}\text { Carbon } \\
\text { (wt. \%) }\end{array}$ & $\begin{array}{c}\text { Atomic H/C } \\
\text { Ratio }\end{array}$ & $\begin{array}{c}\text { Higher } \\
\text { Heating } \\
\text { Value } \\
(\mathrm{MJ} / \mathrm{kg})\end{array}$ & References \\
\hline $\begin{array}{c}\text { Apple } \\
\text { pomace }\end{array}$ & $\begin{array}{l}17 \\
16\end{array}$ & 250 & $\begin{array}{c}0.08 \\
60\end{array}$ & $\begin{array}{l}63.2 \\
69.8\end{array}$ & $\begin{array}{c}0.1 \\
0.02\end{array}$ & $\begin{array}{l}26 \\
28\end{array}$ & {$[60]$} \\
\hline $\begin{array}{c}\text { Apple } \\
\text { pomace }\end{array}$ & $\begin{array}{l}17 \\
12\end{array}$ & $\begin{array}{l}250 \\
300\end{array}$ & 0.08 & $\begin{array}{c}63.2 \\
73\end{array}$ & $\begin{array}{c}0.1 \\
0.06\end{array}$ & $\begin{array}{l}26 \\
32\end{array}$ & {$[60]$} \\
\hline Microalgae & $\begin{array}{l}19.5 \\
12.1\end{array}$ & $\begin{array}{l}222 \\
272\end{array}$ & 0.16 & $\begin{array}{l}52.1 \\
54.3\end{array}$ & $\begin{array}{l}0.14 \\
0.12\end{array}$ & - & [45] \\
\hline Microalgae & $\begin{array}{l}19.5 \\
15.4\end{array}$ & 222 & $\begin{array}{l}0.16 \\
0.58\end{array}$ & $\begin{array}{l}52.1 \\
55.6\end{array}$ & $\begin{array}{l}0.14 \\
0.12\end{array}$ & - & {$[61]$} \\
\hline Microalgae & $\begin{array}{l}28.6 \\
22.7\end{array}$ & $\begin{array}{l}210 \\
250\end{array}$ & 1 & $\begin{array}{l}54.89 \\
27.33\end{array}$ & $\begin{array}{l}0.11 \\
0.12\end{array}$ & - & {$[62]$} \\
\hline $\begin{array}{l}\text { Sewage } \\
\text { sludge }\end{array}$ & 56 & 220 & 0.5 & 7.9 & 0.16 & 3.6 & [46] \\
\hline $\begin{array}{c}\text { Wastewater- } \\
\text { grown } \\
\text { algae }\end{array}$ & - & 350 & 0.5 & 27 & 0.06 & 20.3 & [63] \\
\hline
\end{tabular}

\section{Activation and Functionalization of Hydrochar}

Although hydrochar produced from different hydrothermal technologies through different reaction conditions could show different properties, their physicochemical properties can alter and improve through different modifications. As mentioned earlier, hydrochar generally reveals a low surface area and porosity due to the formation of hydrocarbons on the surface, which hinders its application as contaminant adsorbent and catalysts/catalyst support. The physicochemical properties of hydrochar and its porous structure characteristics such as surface functionalization and physical or chemical activation can be improved by using various modification methods [64,65]. Hydrochar shows surface functional groups and can be effective for hydrochar functionalization such as sulfonating or metal dispersion on hydrochar-derived activated carbon after physical or chemical activation for catalytic applications [66-68].

Chemical activation is carried out over the impregnation of bio/hydrochar with one or a mixture of chemical agents (e.g., acids, oxidizing agents or alkaline solutions), followed by an activation process in a fixed-bed reactor under nitrogen flow rate [69]. Zinc chloride $\left(\mathrm{ZnCl}_{2}\right)$, phosphoric acid $\left(\mathrm{H}_{3} \mathrm{PO}_{4}\right)$, sodium hydroxide $(\mathrm{NaOH})$, potassium carbonate $\left(\mathrm{K}_{2} \mathrm{CO}_{3}\right)$, and potassium hydroxide $(\mathrm{KOH})$ are the most used chemical activating agents for the chemical activation process [70,71].

Alkaline solutions have been widely considered as chemical agents to chemically activate the produced hydrochar to remove the volatile matters resulting in the increasing of the presence of hydrophilic functional groups, such as hydroxyl and carboxylic groups. The presence of such functional groups leads to an increase in the incorporation of the metal elements in the solid surface [65,68]. Masoumi and Dalai [61] investigated the production and characterization of activated carbon from algal hydrochar through chemical activation. The results showed that using $\mathrm{K}_{2} \mathrm{CO}_{3}$ or $\mathrm{KOH}$ at optimum process conditions (temperature of $675{ }^{\circ} \mathrm{C}$, mass ratio of hydrochar and chemical agent (impregnation ratio) of 1.5 and nitrogen flow rate of $267 \mathrm{~cm}^{3} / \mathrm{min}$ ), produced activated carbon with a high surface area $\left(\geq 2100 \mathrm{~m}^{2} / \mathrm{g}\right.$ ) compared to hydrochar with a specific surface area of $4 \mathrm{~m}^{2} / \mathrm{g}$. The said activated carbon was used as catalysts/catalyst supports.

Morali et al. [70] investigated the activated carbon production from meal extracted from sunflower seed through a chemical activation process using $\mathrm{ZnCl}_{2}$ as a chemical 
agent. Based on their results obtained by experimental design, the activation temperature had the most significant effect on the specific surface area. They produced activated carbon with a maximum specific surface area of $1535 \mathrm{~m}^{2} / \mathrm{g}$ using a temperature of $600{ }^{\circ} \mathrm{C}$ and an impregnation ratio of 2. Dai et al. [72] studied the physicochemical properties of carbonized hydrochar from cattle manure and its capacity in recovering nutrients $(\mathrm{P}$ and $\mathrm{N})$ using $0-2 \% \mathrm{HCl}$ solution. When increasing the acid concentration up to $2 \%$, the specific surface area increased by up to $75 \%$, which also extracted almost $100 \%$ of phosphorous and $63.4 \%$ of nitrogen.

Physical or thermal activation can be done through gasification with reactive steam, a gas such as $\mathrm{O}_{2}$ and $\mathrm{CO}_{2}$ or a mixture of steam and $\mathrm{CO}_{2}$ as an oxidizing agent $[73,74]$. Ledesma et al. [75] studied the physical activity process using air to promote the porosity of hydrochar obtained from HTC of almond shells. Their results showed that the time of air exposure through activation is the most important factor to start the oxidation process. Through an oxidation process of up to $23 \mathrm{~min}$, the dissolved oxygen would eliminate the volatile compounds, resulting in increased porosity and a specific surface area of up to 313 $\mathrm{m}^{2} / \mathrm{g}$. Congsomjit and Areeprasert [76] studied the production of porous activated carbon through steam activation (temperature of 700-800 ${ }^{\circ} \mathrm{C}$ ) from hydrochar obtained from the HTC of sugarcane bagasse for its ability to decolorize syrup. They produced hydrochar at two different ranges of temperatures, such as $180-200{ }^{\circ} \mathrm{C}$ and $220-240{ }^{\circ} \mathrm{C}$. Compared to the produced hydrochar with a low surface area, using steam activation, they could increase the specific surface area by up to $390 \mathrm{~m}^{2} / \mathrm{g}$. The hydrochar was produced at a low temperature and could not withstand a steam activation temperature higher than $900{ }^{\circ} \mathrm{C}$. Thus, its specific surface area decreased by increasing the temperature from $800{ }^{\circ} \mathrm{C}$ to 900 ${ }^{\circ} \mathrm{C}$. The carbon structure in hydrochar produced at a lower temperature was weaker, due to a large number of volatile compounds.

Hydrochar functionalization is considered as one of the easiest ways to modify the properties of hydrochar, in which its organic surface is exposed to specific functional groups. The introduction of acid groups such as $\mathrm{SO}_{3} \mathrm{OH}$ or $-\mathrm{COOH}$ into the hydrochar matrix is commonly used for hydrochar modification and makes it suitable as a solid acid catalyst for cellulose hydrolysis or biodiesel production. In this method, acid groups combine with $\mathrm{C}$ atoms on the amorphous carbon layer of the prepared hydrochar to generate phenolic hydroxyl or carboxyl groups on the surface of the solid acidic catalysts $[67,77]$.

Chen et al. [78] studied the production of acidic hydrochar as a promising sustainable catalyst for cellulose hydrolysis, using the functionalization of hydrochar with sulfonic groups. The obtained hydrochar from the low-temperature hydrothermal carbonization process was sulfurized with different $\mathrm{H}_{2} \mathrm{SO}_{4}$ concentrations, which significantly affected the physicochemical properties of the hydrochar, such as yield, morphology, and functional groups present on the surface. Liu and Liu [77] studied the catalytic activity of hydrocharbased solid acid catalysts from biowaste for cellulose degradation. In this study, the catalyst was prepared using the functionalization of hydrochar with $-\mathrm{SO}_{3} \mathrm{H}$ groups. According to thermal gravimetric analysis results upon studying the carbon deposition after reaction, hydrochar produced at a temperature of $240{ }^{\circ} \mathrm{C}$ and sulfonated using concentrated $2 \mathrm{SO}_{4}$ at $150{ }^{\circ} \mathrm{C}$ for $12 \mathrm{~h}$ showed the highest resistance to carbon deposit. The said acidic catalyst exhibited the highest activity towards cellulose conversions in the yielding of glucose and furfural.

The catalytic transesterification reaction of triglycerides from plant oil or animal fat using alcohol (mostly methanol) results in the production of biodiesel as a main product and glycerol as a by-product. One of the challenges of this process, as with other catalytic processes, is to find a renewable and cost-effective catalyst. One of the most commonly used acidic heterogeneous catalysts for biodiesel production is sulfonated hydrochar, which can be easily provided by exposing hydrochar to gaseous $\mathrm{SO}_{3}$ or by impregnating it in concentrated $\mathrm{H}_{2} \mathrm{SO}_{4}[67,79]$. 
Huang et al. [80] studied biodiesel production using solid acid catalysts obtained from carbonizing lignin in supercritical ethanol sulfonated with $\mathrm{H}_{2} \mathrm{SO}_{4}$. The highest biodiesel yield of $95.4 \%$ was obtained from the transesterification of oleic acid at $80{ }^{\circ} \mathrm{C}$ with the heterogeneous acid catalyst synthesized using the carbonization of lignin char in ethanol at $260{ }^{\circ} \mathrm{C}$ for $20 \mathrm{~h}$, followed by sulfonating with $\mathrm{H}_{2} \mathrm{SO}_{4}$ at $150{ }^{\circ} \mathrm{C}$ for $10 \mathrm{~h}$. Moreover, a catalyst reusability study was performed under the following conditions: $80^{\circ} \mathrm{C}$ for $7 \mathrm{~h}$, the methanol-oil molar ratio of 12:1 using $5 \mathrm{wt}$. $\%$ of the catalyst. This catalyst was cycled five times, with biodiesel yields in the range of $82-95 \%$.

\section{Applications of Activated Hydrochar}

\subsection{Agriculture and Crop Improvement}

The adoption of the hydrochar for the application of crop improvement in agricultural sectors depends on the nature of the hydrochar used, the type of feedstock used, the type of the production process and process conditions, the morphological properties, and the nature of the soil, i.e., loamy clay, fertile, sandy, and infertile [81]. However, by applying the hydrochar in the soil, crop yield response could be either productive or counterproductive. The higher surface area and porosity of the hydrochar enhance the soil activity via sufficient aeration to the soil organisms through a supply of water and minerals that protect against infectious diseases [82]. In general, freshly produced hydrochar shows a hydrophobic nature owing to the presence of a low quantity of polar functionality on the surface of the hydrochar. However, when the hydrochar is mixed in the soil, over a period, it becomes oxidized by interacting with atmospheric oxygen and creates a more hydrophilic nature by creating phenolic and carboxylic functional groups on the surface of the hydrochar [83]. Due to the presence of these functionalities on the surface, the water holding capacity, cation exchange capacity, and nutrient retention capacity would increase significantly $[84,85]$.

A vast literature is available on the application of biochar for soil improvement; however, little information is available on the application of hydrochar for this application. Rillig et al. (2010) noticed the positive outcomes on the colonization of arbuscular mycorrhiza fungi and pore germination at $20 \%$ loading of hydrochar derived from beetroot chips in soil [84]. On the other hand, anything beyond a 10\% increment of the hydrochar in soil deteriorates the plant growth of Taraxacum. Schimmelpfennig et al. (2014) reported on a growth experiment via a laboratory incubation study with Lolium perenne using $16 \%$ hydrochar derived from silver grass as a feedstock [86]. During incubation, hydrochar was found to be degraded but did not show a significant impact on the ecosystem's respiration during the field experiments. Further, Bargmann et al. (2013) noticed the unavailability of nitrogen to the plants due to the absence of nitrogen migration in the first week of hydrochar addition. Nevertheless, a slow release of the nitrogen was noticed with time [87]. This behavior suggests that the hydrochar needs to be mixed into the soil for several weeks before planting. Therefore, in-depth research needs to be carried out to evaluate the ecotoxicological properties of the hydrochar and their impact on the soils to lower the negative effects of the hydrochar in soil improvement for agricultural applications.

\subsection{Pollutant Adsorption (from Wastewater and Flue Gases)}

As reported previously, hydrochar has a lower surface area relative to the biochars. However, due to the abundance of the oxygen-rich functionality and the presence of the chemically active functional groups such as ketones, $\mathrm{COOH}$ groups, and hydroxyl on the surface, the adsorption capability of the hydrochar is higher than biochar [88]. Therefore, several studies have been reported on the utilization of hydrochar for mineral and organic pollutants for aqueous solutions. The adsorption efficiency of the hydrochars depends on the physicochemical properties, experimental conditions, and pollutant properties for removal. With an increase in the hydrochar concentration, surface functional groups increase, which are responsible for adsorbing targeted pollutants. Along with higher hydrochar loading, adsorption efficiency increases with solution temperature $[89,90]$. Coffee huskderived hydrochar was produced by Ronix et al. (2017) to remove the methylene blue 
dye from the aqueous solution. The maximum adsorption efficiency was found to be 34.9 $\mathrm{mg} / \mathrm{g}$ of hydrochar at $210^{\circ} \mathrm{C}$ for $4 \mathrm{~h}$ of reaction time [91]. Li et al. (2016) also produced a bamboo-derived hydrochar to adsorb Congo red dye and the maximum adsorption capacity was found to be $97 \mathrm{mg} / \mathrm{g}$ of hydrochar [92]. Regmi et al. (2012) prepared the hydrochar and activated hydrochar via the HTC process, using switchgrass to remove copper and cadmium from the aqueous solution [93]. The outcomes of their investigation revealed that $\mathrm{KOH}$-activated hydrochar showed $100 \%$ adsorption for copper and cadmium in $24 \mathrm{~h}$ relative to the hydrochar and commercially activated carbon. Pinewood and rice husk-derived hydrochars were produced via the HTL technique and applied in the removal of lead from the aqueous solution by Liu and Zhang (2009) [94]. The thermodynamics of the adsorption study revealed that high temperatures favored the adsorption of lead as it is a physical endothermic process.

Further, Fagnani et al. (2019) prepared hydrochar and activated hydrochar from sugarcane bagasse via the hydrocarbonization technique to adsorb $\mathrm{CO}_{2}$ from a simulated flue gas [95]. Activated hydrochar showed a higher affinity for $\mathrm{N}_{2}$ and $\mathrm{CO}_{2}$ at $50{ }^{\circ} \mathrm{C}$, and the maximum selectivity was found to be in the range of $12-50{ }^{\circ} \mathrm{C}$ for $\mathrm{N}_{2}$ and $\mathrm{CO}_{2}$, as per the law of ideal adsorbed solution. Silver fir sawdust-derived hydrochar and activated hydrochar were prepared via the HTC technique by Gallucci et al. (2020) [96]. $\mathrm{CO}_{2}$ capture studies were assayed via pressure swing adsorption and $6.57 \mathrm{mmol} / \mathrm{g}$ of $\mathrm{CO}_{2}$ was adsorbed at 5 bar with hydrochar. This study concluded that hydrochar showed higher adsorption compared to the activated hydrochar and other traditional sorbents. Spataru et al. (2016) attempted to remove orthophosphate (anions) and copper (cations) from wastewater using the hydrochar and activated (enhanced) hydrochar derived from waste sludge from the water treatment plant [97]. Adsorption studies revealed that $97 \%$ of orthophosphates were removed via the enhanced hydrochar at $6 \mathrm{~g} / \mathrm{L}$, which showed a higher adsorption capacity for enhanced hydrochar than raw hydrochar.

\subsection{Catalyst Support}

Hydrochar can alter its physicochemical properties, which leads to the addition of charged surface functionalities to enhance the sorption potential. This section explored the application of hydrochars and activated hydrochars as catalyst materials for enzymatic and heterogeneous catalytic reactions. The schematic representation of the formation of hydrochar, and its adsorption mechanism and enhancement method, is shown in Figure 3 (Fernandez-Sanroman et al., 2021) [98]. Moreover, the utilization of hydrochar in biotechnological processes such as enzyme immobilization would enhance the economic feasibility of industrial applications. Castro et al. (2017) used hydrochar as a scaffold for the immobilization of lectin proteins through a non-covalent technique, i.e., via electrostatic interaction among $\mathrm{COO}^{-}$groups on the surface of the hydrochar and $\mathrm{NH}_{2}$ and $\mathrm{NH}_{3}{ }^{+}$groups of the protein [99]. However, hydrophobic interactions were noticed in the electrostatic interactions, and this binding did not change the protein structure or adhering biological activity. During this study, glucose-derived hydrochar was produced via the HTC technique. Further, cellulase from Trichoderma sp. was immobilized on the hydrochar derived via the low-temperature HTC technique by Primozic et al. (2019) [100]. Enzyme activity was evaluated via adsorption and covalent bonding through a cross-linking reagent from olive oil waste and cellulose-derived hydrochar. Hydrochar derived from cellulose was found to be a suitable carrier for immobilization relative to the olive oil-derived hydrochar, owing to the higher residual activity. Kang et al. (2013) prepared the lignin-, cellulose-, wood meal-, and D-xylose-derived hydrochar via the HTC technique and functionalized it with sulfur for the production of 5-HMF from inulin in ionic liquids using carbon-based sulfonated catalysts in a single step [101]. During the reaction, $47-55 \%$ of $5-\mathrm{HMF}$ yield was received at $100{ }^{\circ} \mathrm{C}$ for $60 \mathrm{~min}$ of the reaction time; hydrochar-based sulfonated catalysts showed higher catalytic activity relative to conventional solid acid catalysts. However, when the sulfonated hydrochar-based catalysts were used in ionic liquids, it was challenging to recover the ionic liquid for reuse from the hydrochar-based catalysts. The utilization of 
hydrochar for catalytic applications would lead to a circular economy and a reduction in the price of biocatalysts and sustainable production. Further, Norouzi et al. (2020) developed a cranberry pomace-derived composite for deoxygenation reactions [102]. Cranberry pomace hydrochar $(\mathrm{CPH})$ and zeolite were introduced to make a composite via the hydrothermal liquefaction technique. Experimental outcomes revealed that cranberry pomace hydrochar was found to be more active relative to zeolite in the conversion of cellulosic sugars into hydrocarbons. However, the presence of the corrosive amino and aliphatic acids hindered the $\mathrm{CPH}$ catalytic activity; nevertheless, the addition of zeolite would overcome these challenges. Therefore, composites of zeolite and $\mathrm{CPH}$ could solve the challenges in biofuel production and assist with the development and commercialization of advanced biofuels from cranberry pomace. Moreover, Norouzi et al. (2021) reported on the preparation of 2D and 3D recyclable zeolite-based composites via the hydrothermal liquefaction of algae [103]. The composites were developed by loading magnetite and commercial zeolite onto/into the algal hydrochar with meso/macro structures. Prepared 2D and 3D catalyst composites were used for the production of heavy gasoline $\left(C_{7}-C_{12}\right)$ and biodiesel $\left(C_{8}-C_{21}\right)$. The 2D architecture of the composites was responsible for the transformation of alkenes into oligomers and ketones, undergoing a series of aldol condensation reactions, whereas the $3 \mathrm{D}$ structure enhanced the local pressure and expelled monomers in the form of gasoline from the catalyst pores. Relative to the 2D structure, the 3D structure is more effective, owing to the presence of $\mathrm{Zn}_{4.00} \mathrm{Fe}_{16.00} \mathrm{Ni}_{4.00} \mathrm{O}_{32.00}$ inside the composite. Converting sewage sludge into hydrogen-rich syngas via hydrochar-derived composites was studied by Gai et al. (2017) [104]. Sewage sludge-derived hydrochar supported with Ni nanoparticles was prepared via one-step hydrothermal carbonization of Ni preloaded sewage sludge. Uniformly dispersed $\mathrm{NiO}$ nanoparticles were generated in situ during the catalytic gasification process and provided the active sites for the adsorption of tar molecules for catalytic conversion. Owing to the strong interactions among the metal cations and carbon support, $\mathrm{Ni}_{0.1} @ \mathrm{HC}$ exhibited the highest catalytic activity in promoting hydrogen production and the reduction of tar under mild conditions. Prepared catalyst composites showed $72.5 \%$ of selectivity for hydrogen, and little or no tar was formed, even at low temperatures i.e., $700-800{ }^{\circ} \mathrm{C}$.

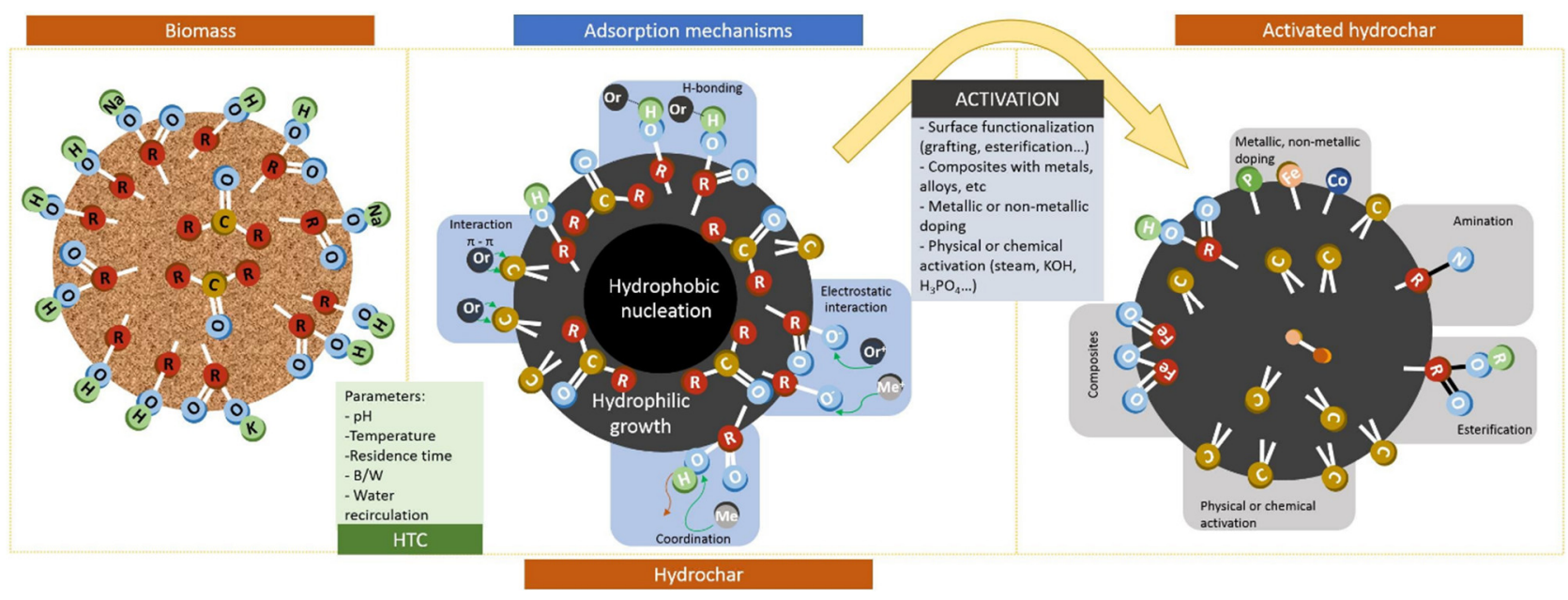

Figure 3. Schematic representation of the formation of hydrochar, its adsorption mechanism, and enhancement method. Reproduced with permission from Fernandez-Sanroman et al. (2021) [98]. Copyright 2021 Elsevier.

\subsection{Energy Production}

The hydrothermal carbonization of raw biomass produces solid residue that can complement coal for energy production. While treating the biomass in the HTC, depolymerization, decomposition, and degradation of polymeric compounds from the biomass takes place. Typical higher heating values for polymeric materials in biomass is as follows: 
lignin $>$ cellulose $>$ hemicellulose $>$ extractives $>$ ash $[105,106]$. Due to the removal of cellulose and hemicellulose during HTC, lignin content increases, which aids as a natural binder in the densification of the HTC residue for coal-like applications. Likewise, during $\mathrm{HTC}$, the $\mathrm{C} / \mathrm{O}$ ratio also increases, which leads to an increase in the higher heating value of the end-product, i.e., the HTC residue. Due to the increase in the lignin or decrease in the hemicellulose content, the hydrophobicity of the HTC residue increases, thereby the shelf life of the HTC residue would be increased without any biodegradation [85,107]. Moreover, when hydrochar is used as a solid fuel, it should satisfy several requirements such as combustion behavior, hydrophobicity, energy density, thermal stability, and grindability [108]. Sadish et al. (2019) prepared hydrochar from effluent treatment plant sludge via HTC technique to use hydrochar for the creating of energy as a supplement to coal [109]. Among all the experimental studies, HTC char produced at $200^{\circ} \mathrm{C}$ for $4 \mathrm{~h}$ showed the highest energy densification (1.24), heating value $(15.25 \mathrm{MJ} / \mathrm{Kg})$, and energy recovery efficiency $(69.8 \%)$. Hydrochar was prepared from the effluent treatment plant sludge from a paper mill under optimized HTC process conditions by Oumabady et al. (2020) [110]. HTC char exhibited $15.6 \%$ of fixed carbon and $18.4 \mathrm{MJ} / \mathrm{Kg}$ heating value; further, reduced $\mathrm{O} / \mathrm{C}$ $(43.7 \%)$ and $\mathrm{H} / \mathrm{C}(35.05 \%)$ ratios confirmed the coalification of the sludge. Blends of the sludge-derived HTC coal and conventional coal (1:1) revealed an HHV of $22.3 \mathrm{MJ} / \mathrm{Kg}$, making it a suitable candidate for heat energy production in paper mills. Wang et al. (2018) used the co-HTC technique to produce hydrochar with increased higher heating value using sludge and food waste [111]. The carbonization temperature was varied to identify the desired HTC temperature for maximum heating value. The addition of the food waste increased the heating value of the hydrochar from 9.6 to 19 and $23 \mathrm{MJ} / \mathrm{Kg}$ at $230{ }^{\circ} \mathrm{C}$ with a 50 and $70 \%$ addition of food waste. Moreover, there was an increment in the heating value, carbon content increased, and ash content decreased with the co-HTC technique.

\subsection{Carbon Sequestration}

The process of storing the biomass-derived hydrochar into the soil is known as carbon capture and storage or carbon sequestration. When the carbon is stored in the soil, it is identical to the net removal of anthropogenic $\mathrm{CO}_{2}$ from the atmosphere. When the carbon sequestration was carried out on purpose, it would lead to a carbon-negative/neutral environment, thereby compensating for the anthropogenic $\mathrm{CO}_{2}$ emissions. The concept of carbon sequestration gained huge interest around the globe due to the encouraging strategy for $\mathrm{CO}_{2}$ mitigation [112,113]. Corn-derived hydrochar was prepared via pyrolysis and the HTC technique by Malghani et al. (2013) for soil amendment as a result of their impact on greenhouse gas emissions and carbon sequestration [114]. The addition of $1 \mathrm{wt} . \%$ hydrochar to the soils resulted in $\mathrm{CH}_{4}$ and $\mathrm{CO}_{2}$ emissions and reduced $\mathrm{N}_{2} \mathrm{O}$ emissions. The increased emissions were due to the rapid decomposition of hydrochar within 100 days after the addition of $50 \mathrm{wt} . \%$ hydrochar. Kammann et al. (2012) and Schimmelpfennig et al. (2014) noticed identical outcomes, i.e., the emission of $\mathrm{CO}_{2}$ and $\mathrm{CH}_{4}$ during their carbon sequestration study using hydrochars derived from ryegrass and peanut hulls and Miscanthus giganteus as feedstocks [86,115]. Relative to the biochar, hydrochar degraded at a faster rate due to the easy biodegradability of the carbon present in the hydrochar. However, in-depth research needs to be carried out to include the applicability of the hydrochar in the soil with a positive impact on agricultural productivity and improved stability.

\subsection{Electrochemical Devices}

Supercapacitors and batteries are some of the products that could utilize the hydrochars for electrochemical devices. Hydrochar has gained attention for these applications due to its lower surface area, polarity, porosity, aromaticity, and stability. This section describes the utilization of hydrochar for the preparation of symmetric supercapacitors. In general, hydrochar-derived supercapacitors exhibit higher cycle stability and power density, whereas rechargeable batteries show lower cycle stability, discharge/charge rate, and a higher energy density [116]. Li and Liu (2014) prepared a walnut shell-derived 
hydrochar, activated hydrochar, and prepared activated hydrochar on $\mathrm{ZnO}$ composites for the making of supercapacitors [41]. The specific surface area of the activated hydrochar on $\mathrm{ZnO}$ and activated hydrochar exhibited 819 and $1073 \mathrm{~m}^{2} / \mathrm{g}$, respectively. Compared to the activated hydrochar, activated hydrochar on $\mathrm{ZnO}$ composite showed $117.4 \mathrm{~F} / \mathrm{g}$ of specific capacitance at a current density of $0.5 \mathrm{~A} / \mathrm{g}$ in $\mathrm{KOH}$ aqueous solution, and it was found to be stable for 1000 cycles. Corn straw-derived hydrochar was activated via microwave-assisted hydrothermal activation technique by Liu et al. (2020) [117]. During the activation time from 40 to $100 \mathrm{~min}$, hydrochar structure was changed to hierarchical pores from micropore structures, i.e., a change of structure from amorphous to graphene-like sheets. Relative to the corn-derived pyro chars, hydrochars showed higher capacitance $(98 \mathrm{~F} / \mathrm{g})$, power, the energy density of $340 \mathrm{~W} / \mathrm{kg}, 96 \mathrm{~W} \mathrm{~h} / \mathrm{kg}$ at $20 \mathrm{~A} / \mathrm{g}$ current density, and electrochemical performance, with a higher specific surface area of $1781 \mathrm{~m}^{2} / \mathrm{g}$. In another study by Ding et al. (2012), rice husk-derived hydrochar was prepared with a sulfuric acid hydrolysis technique [118]. The addition of the hydrochar on Ni significantly improved the specific capacity by $149 \%$, with a specific capacitance of $174.5 \mathrm{~F} / \mathrm{g}$, which was higher than the activated carbon on Ni. Outcomes of the experimental investigations showed that the rice husk-derived hydrochar could be a promising electrode material for the electrochemical supercapacitor. Aside from the super capacitor's applications, hydrochars can also be used as an electrochemical storage device with high surface area, electrical conductivity, easy accessibility, tunable pore structure and size, and excellent mechanical properties. Biomass-derived hydrochars with a well-defined pore structure were found to be ideal hosts for sulfur [78]. Guo et al. (2015) prepared a porous hydrochar with a high surface area using corncobs [119]. Sulfur loaded on hydrochar showed $1600 \mathrm{mAh} / \mathrm{g}$ of discharge capacity, a reversible capacity of $554 \mathrm{mAh} / \mathrm{g}$ after 50 cycles. The unique 2D structure of the hydrochars and the highly specific surface area of the hydrochars resulted in the higher utilization of sulfur that is appropriate for cathode material in lithium-sulfur batteries. Furthermore, Norouzi et al. (2021) reported on the preparation of 3D symmetric and asymmetric types of supercapacitors using algal biomass [120]. The three-dimensional interconnected mesoporous network (3DFAB) of the biochar was prepared through pyrolysis of algae in the presence of the $\mathrm{NaOH}$. During the pyrolysis of microalgae, $\mathrm{NaOH}$ reacted with ester, carboxyl, carbonyl, ether, and hydroxyl functional groups to generate free radicals and various vacant sites. Vacant sites were created owing to the $\mathrm{NaOH}$ reaction with $\mathrm{C}-\mathrm{C}, \mathrm{C}-\mathrm{H}$ groups; further oxygen functional groups were formed by penetration of $\mathrm{OH}$ and $\mathrm{NaOH}$ into the vacant sites. Moreover, $3 \mathrm{DFAB}$ was strengthened by introducing the tile-like architecture of cobalt oxide (CoTLM) via a one-pot hydrothermal technique under mild process conditions. In the case of symmetric supercapacitors, the maximum specific capacitance of the raw algal biomass, 3DFAB, and CoTLM was found to be 158, 296, and $445 \mathrm{~F} / \mathrm{g}$ at $1 \mathrm{~A} / \mathrm{g}$ current density. On the other hand, the asymmetric supercapacitor retained $100.9 \%$ of the initial capacitance after 4000 cycles at $4 \mathrm{~A} / \mathrm{g}$ of current density.

\section{Conclusions}

Waste biomass and organic residues are a storehouse of residual carbohydrates, proteins, lipids, fat, fibers, and other biopolymers that can be efficiently transformed into biofuels, biochemicals, and bioproducts through waste-to-energy technologies. Cellulose, hemicellulose, and lignin comprise an integral part of lignocellulosic biomass. Through thermochemical technologies such as pyrolysis, liquefaction, carbonization, and gasification, waste biomass can be converted to bio-oil, gases, and char. Char is a carbon-rich solid co-product of pyrolysis, carbonization, and gasification along with other biofuel products. Depending on the reaction medium, char can be referred to as biochar or hydrochar. Biochar is mostly used to refer to as char obtained from pyrolysis, carbonization, or conventional gasification of biomass. In contrast, hydrochar is obtained from the hydrothermal carbonization and hydrothermal gasification of biomass in the presence of subcritical or supercritical water. 
Biochar has received much attention globally for its traditional use in improving soil properties and crop productivity despite some newer applications in wastewater treatment, pollutant adsorption, biocomposites, and electrochemistry. In contrast to biochar, hydrochar produced through hydrothermal carbonization and gasification of waste bioresources has also been gaining interest for its eco-friendly production technologies over thermochemical processes for biochar production (i.e., pyrolysis and gasification). Hydrothermal technologies require relatively lower temperatures compared to thermochemical biochar production technologies. This is because of the thermophysical properties of water that become more evident as water transforms to subcritical or supercritical water during hydrothermal carbonization and hydrothermal gasification.

The properties of biochar and hydrochar can be analogous and contrasting in certain aspects of the reaction conditions. Regardless, bio/hydrochar properties are majorly governed by process temperature, reaction time, heating rate, vapor residence time, and feedstock properties (i.e., particle size, moisture, and carbon content, as well as cellulose, hemicellulose, and lignin composition). Higher temperatures and reaction times can lead to an increased specific surface area, porosity, carbon content, heating value and alkalinity of bio/hydrochar. In addition, activation of bio/hydrochar in the presence of physical and/or chemical activation agents can improve the surface area and porosity.

Bio/hydrochar can be applied in a wide variety of applications depending on its physicochemical and morphological properties. Some of the applications of bio/hydrochar discussed in this review article include improvements in soil properties and crop productivity, the adsorption of pollutants from wastewater and industrial emissions, catalyst support, bioenergy production (as a solid fuel), carbon capture (as a carbon-negative agent), and electrochemical devices. The applications of bio/hydrochar are far-fetching, considering the increased interest in clean energy and materials. Novel applications of bio/hydrochar are highly likely to emerge with the continued research efforts in these areas at a global scale. These are some novel discussions that this review article offers in contrast to the existing literature on hydrochar.

Author Contributions: S.M.: Conceptualization, methodology, validation, investigation, writing original draft preparation. V.B.B.: Conceptualization, methodology, validation, investigation, writing original draft preparation. S.N.: Conceptualization, methodology, validation, investigation, writing original draft preparation. A.K.D.: writing-review and editing, supervision, project administration, funding acquisition. All authors have read and agreed to the published version of the manuscript.

Funding: This research was funded by Canada Research Chair (CRC) Program and Natural Sciences and Engineering Research Council of Canada (NSERC).

Acknowledgments: The authors would like to thank the Natural Sciences and Engineering Research Council of Canada (NSERC) and the Canada Research Chairs (CRC) program for funding this research.

Conflicts of Interest: The authors declare no conflict of interest.

\section{References}

1. Gollakota, A.R.K.; Kishore, N.; Gu, S. A review on hydrothermal liquefaction of biomass. Renew. Sustain. Energy Rev. 2018, 81, 1378-1392. [CrossRef]

2. Xu, D.; Lin, G.; Guo, S.; Wang, S.; Guo, Y.; Jing, Z. Catalytic hydrothermal liquefaction of algae and upgrading of biocrude: A critical review. Renew. Sustain. Energy Rev. 2018, 97, 103-118. [CrossRef]

3. Yen, H.W.; Hu, I.C.; Chen, C.Y.; Ho, S.H.; Lee, D.J.; Chang, J.S. Microalgae-based biorefinery-from biofuels to natural products. Bioresour. Technol. 2013, 135, 166-174. [CrossRef] [PubMed]

4. Vassilev, S.V.; Baxter, D.; Andersen, L.K.; Vassileva, C.G. An overview of the chemical composition of biomass. Fuel 2010, 89, 913-933. [CrossRef]

5. Masoumi, S.; Borugadda, V.B.; Dalai, A.K. Biocrude Oil Production via Hydrothermal Liquefaction of Algae and Upgradation Techniques to Liquid Transportation Fuels. In Biorefinery of Alternative Resources: Targeting Green Fuels and Platform Chemicals; Springer: Singapore, 2020; pp. 249-270.

6. Qian, K.; Kumar, A.; Zhang, H.; Bellmer, D.; Huhnke, R. Recent advances in utilization of biochar. Renew. Sustain. Energy Rev. 2015, 42, 1055-1064. [CrossRef] 
7. Cheng, F.; Li, X. Preparation and application of biochar-based catalysts for biofuel production. Catalysts 2018, 8, 346. [CrossRef]

8. Hoekman, S.K.; Broch, A.; Robbins, C.; Zielinska, B.; Felix, L. Hydrothermal carbonization (HTC) of selected woody and herbaceous biomass feedstocks. Biomass Convers. Biorefinery 2013, 3, 113-126. [CrossRef]

9. Shen, Y. A review on hydrothermal carbonization of biomass and plastic wastes to energy products. Biomass Bioenergy 2020, 134, 105479. [CrossRef]

10. Mumme, J.; Eckervogt, L.; Pielert, J.; Diakité, M.; Rupp, F.; Kern, J. Hydrothermal carbonization of anaerobically digested maize silage. Bioresour. Technol. 2011, 102, 9255-9260. [CrossRef]

11. Leng, L.; Huang, H. An overview of the effect of pyrolysis process parameters on biochar stability. Bioresour. Technol. 2018, 270, 627-642. [CrossRef]

12. Papari, S.; Hawboldt, K. A review on condensing system for biomass pyrolysis process. Fuel Process. Technol. 2018, 180, 1-13. [CrossRef]

13. Ayinla, R.T.; Dennis, J.O.; Zaid, H.M.; Sanusi, Y.K.; Usman, F.; Adebayo, L.L. A review of technical advances of recent palm bio-waste conversion to activated carbon for energy storage. J. Clean. Prod. 2019, 229, 1427-1442. [CrossRef]

14. Namazi, A.B.; Allen, D.G.; Jia, C.Q. Benefits of microwave heating method in production of activated carbon. Can. J. Chem. Eng. 2016, 94, 1262-1268. [CrossRef]

15. Hu, B.; Wang, K.; Wu, L.; Yu, S.H.; Antonietti, M.; Titirici, M.M. Engineering carbon materials from the hydrothermal carbonization process of biomass. Adv. Mater. 2010, 22, 813-828. [CrossRef]

16. Martinot, E.; Dienst, C.; Weiliang, L.; Qimin, C. Renewable energy futures: Targets, scenarios, and pathways. Annu. Rev. Environ. Resour. 2007, 32, 205-239. [CrossRef]

17. Lee, J.; Kim, K.H.; Kwon, E.E. Biochar as a catalyst. Renew. Sustain. Energy Rev. 2017, 77, 70-79. [CrossRef]

18. Mohan, D.; Sarswat, A.; Ok, Y.S.; Pittman, C.U., Jr. Organic and inorganic contaminants removal from water with biochar, a renewable, low cost and sustainable adsorbent-a critical review. Bioresour. Technol. 2014, 160, 191-202. [CrossRef]

19. Uchimiya, M.; Wartelle, L.H.; Klasson, K.T.; Fortier, C.A.; Lima, I.M. Influence of pyrolysis temperature on biochar property and function as a heavy metal sorbent in soil. J. Agric. Food Chem. 2011, 59, 2501-2510. [CrossRef]

20. Kambo, H.S.; Dutta, A. A comparative review of biochar and hydrochar in terms of production, physico-chemical properties and applications. Renew. Sustain. Energy Rev. 2015, 45, 359-378. [CrossRef]

21. Dieguez-Alonso, A.; Funke, A.; Anca-Couce, A.; Rombolà, A.G.; Ojeda, G.; Bachmann, J.; Behrendt, F. Towards biochar and hydrochar engineering-Influence of process conditions on surface physical and chemical properties, thermal stability, nutrient availability, toxicity and wettability. Energies 2018, 11, 496. [CrossRef]

22. Kim, D.; Lee, K.; Park, K.Y. Upgrading the characteristics of biochar from cellulose, lignin, and xylan for solid biofuel production from biomass by hydrothermal carbonization. J. Ind. Eng. Chem. 2016, 42, 95-100. [CrossRef]

23. Cao, X.; Peng, X.; Sun, S.; Zhong, L.; Sun, R. Hydrothermal conversion of bamboo: Identification and distribution of the components in solid residue, water-soluble and acetone-soluble fractions. J. Agric. Food Chem. 2014, 62, 12360-12365. [CrossRef] [PubMed]

24. Libra, J.A.; Ro, K.S.; Kammann, C.; Funke, A.; Berge, N.D.; Neubauer, Y.; Emmerich, K.H. Hydrothermal carbonization of biomass residuals: A comparative review of the chemistry, processes and applications of wet and dry pyrolysis. Biofuels 2011, 2, 71-106. [CrossRef]

25. Amonette, J.E.; Joseph, S. Characteristics of biochar: Microchemical properties. In Biochar for Environmental Management; Routledge, Taylor \& Francis Group: London, UK, 2012; pp. 65-84.

26. Nanda, S.; Mohammad, J.; Reddy, S.N.; Kozinski, J.A.; Dalai, A.K. Pathways of lignocellulosic biomass conversion to renewable fuels. Biomass Convers. Biorefinery 2014, 4, 157-191. [CrossRef]

27. Nizamuddin, S.; Baloch, H.A.; Griffin, G.J.; Mubarak, N.M.; Bhutto, A.W.; Abro, R.; Ali, B.S. An overview of effect of process parameters on hydrothermal carbonization of biomass. Renew. Sustain. Energy Rev. 2017, 73, 1289-1299. [CrossRef]

28. Liu, H.; Chen, Y.; Yang, H.; Gentili, F.G.; Söderlind, U.; Wang, X.; Chen, H. Hydrothermal carbonization of natural microalgae containing a high ash content. Fuel 2019, 249, 441-448. [CrossRef]

29. Xiao, L.P.; Shi, Z.J.; Xu, F.; Sun, R.C. Hydrothermal carbonization of lignocellulosic biomass. Bioresour. Technol. 2012, 118, 619-623. [CrossRef] [PubMed]

30. Liu, Z.; Quek, A.; Hoekman, S.K.; Balasubramanian, R. Production of solid biochar fuel from waste biomass by hydrothermal carbonization. Fuel 2013, 103, 943-949. [CrossRef]

31. Gascó, G.; Paz-Ferreiro, J.; Álvarez, M.L.; Saa, A.; Méndez, A. Biochars and hydrochars prepared by pyrolysis and hydrothermal carbonisation of pig manure. Waste Manag. 2018, 79, 395-403. [CrossRef]

32. Abdelhafez, A.A.; Abbas, M.H.; Li, J. Biochar: The black diamond for soil sustainability, contamination control and agricultural production. Eng. Appl. Biochar 2017, 2, 2-8. [CrossRef]

33. Singh, A.; Nanda, S.; Guayaquil Sosa, F.; Berruti, F. Pyrolysis of Miscanthus and characterization of value-added bio-oil and biochar products. Can. J. Chem. Eng. 2021. [CrossRef]

34. Angin, D. Effect of pyrolysis temperature and heating rate on biochar obtained from pyrolysis of safflower seed press cake. Bioresour. Technol. 2013, 128, 593-597. [CrossRef] [PubMed]

35. Schimmelpfennig, S.; Glaser, B. One step forward toward characterization: Some important material properties to distinguish biochars. J. Environ. Qual. 2012, 41, 1001-1013. [CrossRef] [PubMed] 
36. Chun, Y.; Sheng, G.; Chiou, C.T.; Xing, B. Compositions and sorptive properties of crop residue-derived chars. Environ. Sci. Technol. 2004, 38, 4649-4655. [CrossRef]

37. Elliott, D.C. Review of recent reports on process technology for thermochemical conversion of whole algae to liquid fuels. Algal Res. 2016, 13, 255-263. [CrossRef]

38. Kumar, M.; Oyedun, A.O.; Kumar, A. A review on the current status of various hydrothermal technologies on biomass feedstock. Renew. Sustain. Energy Rev. 2018, 81, 1742-1770. [CrossRef]

39. Sharma, R.; Jasrotia, K.; Singh, N.; Ghosh, P.; Sharma, N.R.; Singh, J.; Kumar, A. A comprehensive review on hydrothermal carbonization of biomass and its applications. Chem. Afr. 2020, 3, 1-19. [CrossRef]

40. Tekin, K.; Karagöz, S.; Bektaş, S. A review of hydrothermal biomass processing. Renew. Sustain. Energy Rev. 2014, 40, 673-687. [CrossRef]

41. Zhang, Z.; Zhu, Z.; Shen, B.; Liu, L. Insights into biochar and hydrochar production and applications: A review. Energy 2019, 171, 581-598. [CrossRef]

42. Broch, A.; Jena, U.; Hoekman, S.K.; Langford, J. Analysis of solid and aqueous phase products from hydrothermal carbonization of whole and lipid-extracted algae. Energies 2014, 7, 62-79. [CrossRef]

43. Toor, S.S.; Rosendahl, L.; Rudolf, A. Hydrothermal liquefaction of biomass: A review of subcritical water technologies. Energy 2011, 36, 2328-2342. [CrossRef]

44. Elliott, D.C.; Hart, T.R.; Schmidt, A.J.; Neuenschwander, G.G.; Rotness, L.J.; Olarte, M.V.; Holladay, J.E. Process development for hydrothermal liquefaction of algae feedstocks in a continuous-flow reactor. Algal. Res. 2013, 2, 445-454. [CrossRef]

45. Masoumi, S.; Boahene, P.E.; Dalai, A.K. Biocrude oil and hydrochar production and characterization obtained from hydrothermal liquefaction of microalgae in methanol-water system. Energy 2021, 217, 119344. [CrossRef]

46. Lai, F.Y.; Chang, Y.C.; Huang, H.J.; Wu, G.Q.; Xiong, J.B.; Pan, Z.Q.; Zhou, C.F. Liquefaction of sewage sludge in ethanol-water mixed solvents for bio-oil and biochar products. Energy 2018, 148, 629-641. [CrossRef]

47. Feng, H.; Zhang, B.; He, Z.; Wang, S.; Salih, O.; Wang, Q. Study on co-liquefaction of Spirulina and Spartina alterniflora in ethanol-water co-solvent for bio-oil. Energy 2018, 155, 1093-1101. [CrossRef]

48. Zhang, J.; Zhang, Y.; Luo, Z. Hydrothermal liquefaction of chlorella pyrenoidosa in ethanol-water for bio-crude production. Energy Procedia 2014, 61, 1961-1964. [CrossRef]

49. Azadi, P.; Farnood, R. Review of heterogeneous catalysts for sub-and supercritical water gasification of biomass and wastes. Int. J. Hydrog. Energy 2011, 36, 9529-9541. [CrossRef]

50. Okolie, J.A.; Nanda, S.; Dalai, A.K.; Kozinski, J.A. Optimization and modeling of process parameters during hydrothermal gasification of biomass model compounds to generate hydrogen-rich gas products. Int. J. Hydrog. Energy 2020, 45, 18275-18288. [CrossRef]

51. Yang, C.; Wang, S.; Yang, J.; Xu, D.; Li, Y.; Li, J.; Zhang, Y. Hydrothermal Liquefaction and Gasification of Biomass and Model Compounds: A Review; Green Chemistry: Lodon, UK, 2020.

52. Yao, Z.; Ma, X. Hydrothermal carbonization of Chinese fan palm. Bioresour. Technol. 2019, 282, 28-36. [CrossRef] [PubMed]

53. Salaudeen, S.A.; Acharya, B.; Dutta, A. Steam gasification of hydrochar derived from hydrothermal carbonization of fruit wastes. Renew. Energy 2021, 171, 582-591. [CrossRef]

54. Guo, S.; Dong, X.; Zhu, C.; Han, Y.; Ma, F.; Wu, T. Pyrolysis behaviors and thermodynamics properties of hydrochar from bamboo (Phyllostachys heterocycla cv. pubescens) shoot shell. Bioresour. Technol. 2017, 233, 92-98. [CrossRef] [PubMed]

55. Zhang, L.; Liu, S.; Wang, B.; Wang, Q.; Yang, G.; Chen, J. Effect of residence time on hydrothermal carbonization of corn cob residual. BioResources 2015, 10, 3979-3986. [CrossRef]

56. Zhu, G.; Yang, L.; Gao, Y.; Xu, J.; Chen, H.; Zhu, Y.; Zhu, C. Characterization and pelletization of cotton stalk hydrochar from HTC and combustion kinetics of hydrochar pellets by TGA. Fuel 2019, 244, 479-491. [CrossRef]

57. Shao, Y.; Tan, H.; Shen, D.; Zhou, Y.; Jin, Z.; Zhou, D.; Long, Y. Synthesis of improved hydrochar by microwave hydrothermal carbonization of green waste. Fuel 2020, 266, 117146. [CrossRef]

58. Yan, W.; Perez, S.; Sheng, K. Upgrading fuel quality of moso bamboo via low temperature thermochemical treatments: Dry torrefaction and hydrothermal carbonization. Fuel 2017, 196, 473-480. [CrossRef]

59. Kalderis, D.; Kotti, M.S.; Méndez, A.; Gascó, G. Characterization of hydrochars produced by hydrothermal carbonization of rice husk. Solid Earth 2014, 5, 477-483. [CrossRef]

60. Li, C.; Yang, X.; Zhang, Z.; Zhou, D.; Zhang, L.; Zhang, S.; Chen, J. Hydrothermal liquefaction of desert shrub Salix psammophila to high value-added chemicals and hydrochar with recycled processing water. BioResources 2013, 8, 2981-2997. [CrossRef]

61. Masoumi, S.; Dalai, A.K. Optimized production and characterization of highly porous activated carbon from algal-derived hydrochar. J. Clean. Prod. 2020, 263, 121427. [CrossRef]

62. Saber, M.; Takahashi, F.; Yoshikawa, K. Characterization and application of microalgae hydrochar as a low-cost adsorbent for Cu (II) ion removal from aqueous solutions. Environ. Sci. Pollut. Res. 2018, 25, 32721-32734. [CrossRef]

63. Yu, J.; Tang, T.; Cheng, F.; Huang, D.; Martin, J.L.; Brewer, C.E.; Luo, H. Waste-to-wealth application of wastewater treatment algae-derived hydrochar for $\mathrm{Pb}$ (II) adsorption. MethodsX 2021, 8, 101263. [CrossRef]

64. Kołtowski, M.; Charmas, B.; Skubiszewska-Zięba, J.; Oleszczuk, P. Effect of biochar activation by different methods on toxicity of soil contaminated by industrial activity. Ecotoxicol. Environ. Saf. 2017, 136, 119-125. [CrossRef] [PubMed] 
65. Tan, X.F.; Liu, S.B.; Liu, Y.G.; Gu, Y.L.; Zeng, G.M.; Hu, X.J.; Jiang, L.H. Biochar as potential sustainable precursors for activated carbon production: Multiple applications in environmental protection and energy storage. Bioresour. Technol. 2017, 227, 359-372. [CrossRef]

66. Masoumi, S.; Dalai, A.K. NiMo carbide supported on algal derived activated carbon for hydrodeoxygenation of algal biocrude oil. Energy Convers. Manag. 2021, 231, 113834. [CrossRef]

67. Cao, X.; Sun, S.; Sun, R. Application of biochar-based catalysts in biomass upgrading: A review. RSC Adv. 2017, 7, 48793-48805. [CrossRef]

68. Azzaz, A.A.; Khiari, B.; Jellali, S.; Ghimbeu, C.M.; Jeguirim, M. Hydrochars production, characterization and application for wastewater treatment: A review. Renew. Sustain. Energy Rev. 2020, 127, 109882. [CrossRef]

69. Ao, W.; Fu, J.; Mao, X.; Kang, Q.; Ran, C.; Liu, Y.; Dai, J. Microwave assisted preparation of activated carbon from biomass: A review. Renew. Sustain. Energy Rev. 2018, 92, 958-979. [CrossRef]

70. Moralı, U.; Demiral, H.; Şensöz, S. Optimization of activated carbon production from sunflower seed extracted meal: Taguchi design of experiment approach and analysis of variance. J. Clean. Prod. 2018, 189, 602-611. [CrossRef]

71. Sulaiman, N.S.; Hashim, R.; Amini, M.H.M.; Danish, M.; Sulaiman, O. Optimization of activated carbon preparation from cassava stem using response surface methodology on surface area and yield. J. Clean. Prod. 2018, 198, 1422-1430. [CrossRef]

72. Dai, L.; Yang, B.; Li, H.; Tan, F.; Zhu, N.; Zhu, Q.; Hu, G. A synergistic combination of nutrient reclamation from manure and resultant hydrochar upgradation by acid-supported hydrothermal carbonization. Bioresour. Technol. 2017, 243, 860-866. [CrossRef] [PubMed]

73. Cha, J.S.; Park, S.H.; Jung, S.C.; Ryu, C.; Jeon, J.K.; Shin, M.C.; Park, Y.K. Production and utilization of biochar: A review. J. Ind. Eng. Chem. 2016, 40, 1-15. [CrossRef]

74. Xiong, X.; Iris, K.M.; Cao, L.; Tsang, D.C.; Zhang, S.; Ok, Y.S. A review of biochar-based catalysts for chemical synthesis, biofuel production, and pollution control. Bioresour. Technol. 2017, 246, 254-270. [CrossRef]

75. Ledesma, B.; Olivares-Marín, M.; Álvarez-Murillo, A.; Roman, S.; Nabais, J.V. Method for promoting in-situ hydrochar porosity in hydrothermal carbonization of almond shells with air activation. J. Supercrit. Fluids 2018, 138, 187-192. [CrossRef]

76. Congsomjit, D.; Areeprasert, C. Hydrochar-derived activated carbon from sugar cane bagasse employing hydrothermal carbonization and steam activation for syrup decolorization. Biomass Convers. Biorefinery 2020. [CrossRef]

77. Liu, Z.; Liu, Z. Comparison of hydrochar-and pyrochar-based solid acid catalysts from cornstalk: Physiochemical properties, catalytic activity and deactivation behavior. Bioresour. Technol. 2020, 297, 122477. [CrossRef]

78. Cheng, B.H.; Zeng, R.J.; Jiang, H. Recent developments of post-modification of biochar for electrochemical energy storage. Bioresour. Technol. 2017, 246, 224-233. [CrossRef]

79. Tang, Z.E.; Lim, S.; Pang, Y.L.; Ong, H.C.; Lee, K.T. Synthesis of biomass as heterogeneous catalyst for application in biodiesel production: State of the art and fundamental review. Renew. Sustain. Energy Rev. 2018, 92, 235-253. [CrossRef]

80. Huang, M.; Luo, J.; Fang, Z.; Li, H. Biodiesel production catalyzed by highly acidic carbonaceous catalysts synthesized via carbonizing lignin in sub-and super-critical ethanol. Appl. Catal. B Environ. 2016, 190, 103-114. [CrossRef]

81. Sohi, S.; Krull, E.; Lopez-Capel, E.; Bol, R. A review of biochar and its use and function in soil. Adv. Agron. $2010,105,47-82$.

82. Warnock, D.D.; Lehmann, J.; Kuyper, T.W.; Rillig, M.C. Mycorrhizal responses to biochar in soil-concepts and mechanisms. Plant Soil 2017, 300, 9-20. [CrossRef]

83. Cheng, C.H.; Lehmann, J.; Engelhard, M.H. Natural oxidation of black carbon in soils: Changes in molecular form and surface charge along a climosequence. Geochim. Cosmochim. Acta 2008, 72, 1598-1610. [CrossRef]

84. Rillig, M.C.; Wagner, M.; Salem, M.; Antunes, P.M.; George, C.; Ramke, H.G.; Titirici, M.M.; Antonietti, M. Material derived from hydrothermal carbonization: Effects on plant growth and arbuscular mycorrhiza. Appl. Soil Ecol. 2010, 45, 238-242. [CrossRef]

85. Kambo, H.S.; Strength, D.A. Storage, and combustion characteristics of densified lignocellulosic biomass produced via torrefaction and hydrothermal carbonization. Appl. Energy 2014, 135, 182-191. [CrossRef]

86. Schimmelpfennig, S.; Muller, C.; Grunhage, L.; Koch, C.; Kammann, C. Biochar, hydrochar and uncarbonized feedstock application to permanent grassland-Effects on greenhouse gas emissions and plant growth. Agric. Ecosyst. Environ. 2014, 191, 39-52 [CrossRef]

87. Bargmann, I.; Rillig, M.C.; Kruse, A.; Greef, J.M.; Kucke, M. Effects of hydrochar application on the dynamics of soluble nitrogen in soils and on plant availability. J. Plant Nutr. Soil Sci. 2014, 177, 48-58. [CrossRef]

88. Qambrani, N.A.; Rahman, M.M.; Won, S.; Shim, S.; Ra, C. Biochar properties and eco-friendly applications for climate change mitigation, waste management, and wastewater treatment: A review. Renew. Sustain. Energy Rev. 2017, 79, 255-273. [CrossRef]

89. Xue, Y.; Gao, B.; Yao, Y.; Inyang, M.; Zhang, M.; Zimmerman, A.R.; Ro, K.S. Hydrogen peroxide modification enhances the ability of biochar (hydrochar) produced from hydrothermal carbonization of peanut hull to remove aqueous heavy metals: Batch and column tests. Chem. Eng. J. 2012, 200-202, 673-680. [CrossRef]

90. Fang, J.; Gao, B.; Chen, J.; Zimmerman, A.R. Hydrochars derived from plant biomass under various conditions: Characterization and potential applications and impacts. Chem. Eng. J. 2015, 267, 253-259. [CrossRef]

91. Ronix, A.; Pezoti, O.; Souza, L.S.; Souza, I.P.A.F.; Bedin, K.C.; Souza, P.S.C.; Silva, T.S.; Melo, S.A.R.; Cazetta, A.L.; Almeida, V.C. Hydrothermal carbonization of coffee husk: Optimization of experimental parameters and adsorption of methylene blue dye. J. Environ. Chem. Eng. 2017, 5, 4841-4849. [CrossRef] 
92. Li, Y.; Meas, A.; Shan, S.; Yang, R.; Gai, X. Bioresource Technology Production and optimization of bamboo hydrochars for adsorption of Congo red and 2-naphthol. Bioresour. Technol. 2016, 207, 379-386. [CrossRef]

93. Regmi, P.; Moscoso, J.L.G.; Kumar, S.; Cao, X.; Mao, J.; Schafran, G. Removal of copper and cadmium from aqueous solution using switchgrass biochar produced via hydrothermal carbonization process. J. Environ. Manag. 2012, 109, 61-69. [CrossRef]

94. Liu, H.; Zhang, F.S. Removal of lead from water using biochars prepared from hydrothermal liquefaction of biomass. J. Hazard. Mater. 2009, 167, 933-939. [CrossRef] [PubMed]

95. Fagnani, H.M.C.; da Silva, C.T.P.; Pereira, M.M.; Rinaldi, A.W.; Arroyo, P.A.; de Barros, M.A.S.D. $\mathrm{CO}_{2}$ adsorption in hydrochar produced from waste biomass. SN Appl. Sci. 2019, 1, 1031. [CrossRef]

96. Gallucci, K.; Taglieri, L.; Papa, A.A.; Lauro, F.D.; Ahmad, Z.; Gallifuoco, A. Non-Energy Valorization of Residual Biomasses via HTC: CO2 Capture onto Activated Hydrochars. Appl. Sci. 2020, 10, 1879. [CrossRef]

97. Spataru, A.; Jain, R.; Chung, J.W.; Gerner, G.; Krebs, R.; Lens, P.N.L. Enhanced adsorption of orthophosphate and copper onto hydrochar derived from sewage sludge by KOH activation. RSC Adv. 2016, 6, 101827-101834. [CrossRef]

98. Fernandez-Sanroman, A.; Lama, G.; Pazos, M.; Rosales, E.; Sanroman, M.A. Bridging the gap to hydrochar production and its application into frameworks of bioenergy, environmental and biocatalysis areas. Bioresour. Technol. 2021, 320, 124399. [CrossRef]

99. Castro, M.O.; de Santiago, M.Q.; Nascimiento, K.S.; Cavada, B.S.; de Castro Miguel, E.; de Paula, A.J.; Ferreira, O.P. Hydrochar as protein support: Preservation of biomolecule properties with non-covalent immobilization. J. Material. Sci. 2017, 52, 13378-13389. [CrossRef]

100. Primozic, M.; Podrepsek, G.H.; Pavlovic, I.; Skerget, M.; Knez, Z.; Leitgeb, M. Enzyme immobilization onto biochar produced by the hydrothermal carbonization of biomass. Acta Chim. Slov. 2019, 66, 732-739. [CrossRef]

101. Kang, S.; Ye, J.; Zhang, Y.; Chang, J. Preparation of biomass hydrochar derived sulfonated catalysts and their catalytic effects for 5-hydroxymethylfurfural production. RSC Adv. 2013, 3, 7360-7366. [CrossRef]

102. Norouzi, O.; Heidari, M.; Martinez, M.M.; Dutta, A. New Insights for the Future Design of Composites Composed of Hydrochar and Zeolite for Developing Advanced Biofuels from Cranberry Pomace. Energies 2020, 13, 6600. [CrossRef]

103. Norouzi, O.; Heidari, M.; Maria, F.D.; Dutta, A. Design of a ternary 3D composite from hydrochar, zeolite and magnetite powder for direct conversion of biomass to gasoline. Chem. Eng. J. 2021, 410, 128323. [CrossRef]

104. Gai, C.; Zhang, F.; Guo, Y.; Peng, N.; Liu, T.; Lang, Q.; Xia, Y.; Liu, Z. Hydrochar-Supported, in Situ-Generated Nickel Nanoparticles for Sorption-Enhanced Catalytic Gasification of Sewage Sludge. ACS Sustain. Chem. Eng. 2017, 5, 7613-7622. [CrossRef]

105. Falco, C.; Marco-Lozar, J.P.; Salinas-Torres, D.; Morallon, E.; Cazorla-Amoros, D.; Titirici, M.M. Tailoring the porosity of chemically activated hydrothermal carbons: Influence of the precursor and hydrothermal carbonization temperature. Carbon 2013, 62, 346-355. [CrossRef]

106. Reza, M.T.; Andert, J.; Wirth, B.; Busch, D.; Pielert, J.; Lynam, J.G.; Mumme, J. Hydrothermal carbonization of biomass for energy and crop production. Appl. Bioenergy 2014, 1, 11-29. [CrossRef]

107. Reza, M.T.; Lynam, J.G.; Vasquez, V.R.; Coronella, C.J. Pelletization of biochar from hydrothermally carbonized wood. Environ. Prog. Sustain. Energy 2012, 31, 225-234. [CrossRef]

108. Liu, X.V.; Hoekman, S.K.; Farthing, W.; Felix, L. TC2015: Life cycle analysis of co-formed coal fines and hydrochar produced in twin-screw extruder (TSE). Environ. Prog. Sustain. Energy 2017, 36, 668-676. [CrossRef]

109. Sadish, O.; Sebastian, S.P.; Banu, K.S.P.; Mahendran, R. Hydrochar as an Energy Alternative to Coal: Effect of Temperature on Hydrothermal Carbonization of Paper Board Mill Sludge. Int. J. Curr. Microbiol. Appl. Sci. 2019, 8, 1668-1675. [CrossRef]

110. Oumabady, S.; Sebastian, P.S.; Kamaludeen, S.P.B.; Ramasamy, M.; Kalaiselvi, P.; Parameswari, E. Preparation and Characterization of Optimized Hydrochar from Paper Board Mill Sludge. Sci. Rep. 2020, 10, 773. [CrossRef]

111. Wang, T.; Zhai, Y.; Zhu, Y.; Gan, X.; Zheng, L.; Peng, C.; Wang, B.; Li, C.; Zeng, G. Evaluation of the clean characteristics and combustion behavior of hydrochar derived from food waste towards solid biofuel production. Bioresour. Technol. 2018, 266, 275-283. [CrossRef] [PubMed]

112. Gaunt, J.L.; Lehmann, J. Energy balance and emissions associated with biochar sequestration and pyrolysis bioenergy production. Environ. Sci. Technol. 2008, 42, 4152-4158. [CrossRef] [PubMed]

113. Lee, J.W.; Hawkins, B.; Day, D.M.; Reicosky, D.C. Sustainability: The capacity of smokeless biomass pyrolysis for energy production, global carbon capture and sequestration. Energy Environ. Sci. 2010, 3, 1695-1705. [CrossRef]

114. Liu, D.; Wang, Y.; Jia, B.; Wei, J.; Liu, C.; Zhu, J.; Tang, S.; Wu, S.; Chen, G. Microwave-Assisted Hydrothermal Preparation of Corn Straw Hydrochar as Supercapacitor Electrode Materials. ACS Omega 2020, 5, 26084-26093. [CrossRef]

115. Malghani, S.; Gleixner, G.; Trumbore, S.E. Chars produced by slow pyrolysis and hydrothermal carbonization vary in carbon sequestration potential and greenhouse gases emissions. Soil Biol. Biochem. 2013, 62, 137-146. [CrossRef]

116. Kammann, C.; Ratering, S.; Eckhard, C.; Müller, C. Biochar and hydrochar effects on greenhouse gas (carbon dioxide, nitrous oxide, and methane) fluxes from soils. J. Environ. Qual. 2012, 41, 1052-1066. [CrossRef] [PubMed]

117. Li, Y.; Liu, X. Activated carbon/ZnO composites prepared using hydrochars as intermediate and their electrochemical performance in supercapacitor. Mater. Chem. Phys. 2014, 148, 380-386. [CrossRef]

118. Ding, L.; Wang, Z.; Li, Y.; Du, Y.; Liu, H.; Guo, Y. A novel hydrochar and nickel composite for the electrochemical supercapacitor electrode material. Mater. Lett. 2012, 74, 111-114. [CrossRef] 
119. Guo, J.; Zhang, J.; Jiang, F.; Zhao, S.; Su, Q.; Du, G. Microporous carbon nanosheets derived from corncobs for lithium-sulfur batteries. Electrochim. Acta 2015, 176, 853-860. [CrossRef]

120. Norouzi, O.; Pourhosseini, S.E.M.; Nader, H.R.; Maria, F.D.; Dutta, A. Integrated hybrid architecture of metal and biochar for high performance asymmetric supercapacitors. Sci. Rep. 2021, 11, 5387. [CrossRef] 